\title{
Association between inflammatory mediators and response to inhaled nitric oxide in a model of endotoxin-induced lung injury
}

\author{
Sebastien Trachsel ${ }^{1,2}$, Ginette Deby-Dupont ${ }^{3,4}$, Edwige Maurenbrecher ${ }^{1}$, Monique Nys ${ }^{3,4}$, \\ Maurice Lamy ${ }^{3,4}$ and Göran Hedenstierna ${ }^{1}$
}

\author{
1Department of Medical Sciences, Clinical Physiology, Uppsala University, S-75185 Uppsala, Sweden \\ 2Department of Anesthesiology, University Hospital, Inselspital Bern, CH-3010 Bern, Switzerland \\ ${ }^{3}$ Department of Anaesthesia and Intensive Care Medicine, University Hospital of Liège, Domaine du Sart Tilman - B35, B-4000, Liège, Belgium \\ ${ }^{4}$ Centre for Oxygen Research and Development, Institute of Chemistry, B6a, University of Liège, Sart Tilman, Belgium University of Liège, B-4000 \\ Liege, Belgium \\ Corresponding author: Göran Hedenstierna, goran.hedenstierna@akademiska.se
}

Received: 25 Jul 2008 Revisions requested: 21 Aug 2008 Revisions received: 16 Sep 2008 Accepted: 27 Oct 2008 Published: 27 Oct 2008

Critical Care 2008, 12:R131 (doi:10.1186/cc7099)

This article is online at: http://ccforum.com/content/12/5/R131

(c) 2008 Trachsel et al.; licensee BioMed Central Ltd.

This is an open access article distributed under the terms of the Creative Commons Attribution License (http://creativecommons.org/licenses/by/2.0), which permits unrestricted use, distribution, and reproduction in any medium, provided the original work is properly cited.

\begin{abstract}
Introduction Inhaled nitric oxide (INO) allows selective pulmonary vasodilation in acute respiratory distress syndrome and improves $\mathrm{PaO}_{2}$ by redistribution of pulmonary blood flow towards better ventilated parenchyma. One-third of patients are nonresponders to INO, however, and it is difficult to predict who will respond. The aim of the present study was to identify, within a panel of inflammatory mediators released during endotoxininduced lung injury, specific mediators that are associated with a $\mathrm{PaO}_{2}$ response to INO.

Methods After animal ethics committee approval, pigs were anesthetized and exposed to 2 hours of endotoxin infusion. Levels of cytokines, prostanoid, leucotriene and endothelin-1 (ET-1) were sampled prior to endotoxin exposure and hourly thereafter. All animals were exposed to $40 \mathrm{ppm}$ INO: 28 animals were exposed at either 4 hours or 6 hours and a subgroup of nine animals was exposed both at 4 hours and 6 hours after onset of endotoxin infusion.
\end{abstract}

Results Based on the response to INO, the animals were retrospectively placed into a responder group (increase in $\mathrm{PaO}_{2}$ $\geq 20 \%$ ) or a nonresponder group. All mediators increased with endotoxin infusion although no significant differences were seen between responders and nonresponders. There was a mean difference in ET-1, however, with lower levels in the nonresponder group than in the responder group, $0.1 \mathrm{pg} / \mathrm{ml}$ versus $3.0 \mathrm{pg} / \mathrm{ml}$. Moreover, five animals in the group exposed twice to INO switched from responder to nonresponder and had decreased ET-1 levels (3.0 (2.5 to 7.5$) \mathrm{pg} / \mathrm{ml}$ versus 0.1 ( 0.1 to 2.1) $\mathrm{pg} / \mathrm{ml}, P<0.05)$. The pulmonary artery pressure and ET-1 level were higher in future responders to INO.

Conclusions ET-1 may therefore be involved in mediating the response to INO.

\section{Introduction}

Despite years of research and efforts for specific treatments of acute respiratory distress syndrome (ARDS), mortality remains significant [1]. A symptomatic approach aimed at fluid restriction, diuresis, reducing pulmonary hypertension and improving arterial oxygenation are the goals of therapy. The use of intravenous vasodilators to reduce pulmonary hypertension is limited because of deleterious side effects. Arterial oxygenation may worsen because of increased blood flow to nonventilated areas of the lung and systemic effects that can result in hypotension [2]. Inhaled nitric oxide (INO) allows selective pulmonary vasodilation and improves arterial oxygenation by redistribution of blood flow towards better ventilated parenchyma [3]. The clinical application of INO in ARDS and septic shock is still not definitive, however, and fails to show an improved outcome in ARDS [4-6]. Moreover, septic shock

ARDS: acute respiratory distress syndrome; ET-1: endothelin-1; IL: interleukin; INO: inhaled nitric oxide; 6-keto-PGF ${ }_{1 \alpha}$ : 6-keto-prostaglandin F 1 alpha; $\mathrm{LTB}_{4}$ : leukotriene $\mathrm{B}_{4} ; \mathrm{MPAP}$ : mean pulmonary arterial pressure; $\mathrm{NO}$ : nitric oxide; $\mathrm{PaCO}_{2}$ : arterial carbon dioxide partial pressure; $\mathrm{PaO} \mathrm{O}_{2}$ : arterial oxygen partial pressure; $\mathrm{PaO}_{2} / \mathrm{FiO}_{2}$ : ratio of arterial oxygen partial pressure to inspired oxygen fraction; $\mathrm{PGF}_{2 \alpha}$ : prostaglandin $\mathrm{F} 2$ alpha; TNF $\alpha$ : tumor necrosis factor alpha; $\mathrm{TXB}_{2}$ : thromboxane $\mathrm{B}_{2}$. 
appears to be a condition associated with blunted response to INO [7] and nonresponse to INO occurs in about one-third of patients with ARDS [8].

Mechanisms of nonresponse to nitric oxide (NO) are proposed but remain inconclusive [9]. No indepth studies have been performed focusing on the systemic release of vasoactive inflammatory mediators and subsequent INO administration. We previously developed an experimental model of endotoxin infusion in pigs and tested the degree of response to INO 4 hours and 6 hours after onset of an endotoxin infusion [10]: a positive response, defined as a $20 \% \mathrm{PaO}_{2}$ increase, was observed in most animals at 4 hours but not at 6 hours. This present report includes results from 28 animals. The aim of the study was to compare physiological and biochemical events to try to elucidate the mechanisms of response and nonresponse to INO in an endotoxin-induced animal lung injury model.

\section{Materials and methods Animals}

After approval of the local Animal Research Ethical committee, 30 pathogen-free pigs (mixed Hampshire, Yorkshire and land race breeds) of either sex submitted to regular health testing were studied. Two pigs died before completion of the study, making a total of 28 pigs weighing $26.2 \pm 1.0 \mathrm{~kg}$.

\section{Experimental protocol}

\section{Anesthesia and catheterization}

The protocol has been described previously [10]. After induction of anesthesia and tracheal intubation, mechanical ventilation (volume-cycled mode, Servo 900C; Siemens-Elema AB, Lund, Sweden) was performed with the following baseline settings: tidal volume, $10 \mathrm{ml} / \mathrm{kg}$ at 20 breaths/minute; inspiration to expiration ratio, $1: 2 ; \mathrm{FiO}_{2}, 0.5$; positive end-expiratory pressure, $5 \mathrm{cmH}_{2} \mathrm{O}$. The tidal volume was adjusted hourly to maintain normoventilation using the end-tidal carbon dioxide level as a guide $(38.3 \pm 0.5 \mathrm{mmHg})$.

Anesthesia was maintained by continuous infusion of clomethiazole (400 mg/hour, Heminevrin; Astra, Södertälje, Sweden), fentanyl (150 $\mu \mathrm{g} /$ hour) and pancuronium ( $2.5 \mathrm{mg} / \mathrm{hour})$. Ringer acetate solution $(1,000 \mathrm{ml}$; Pharmacia, Stockholm, Sweden) was infused before baseline measurements, in conditions to obtain a stable systemic pressure and a stable hemoglobin concentration $(84 \pm 1.1 \mathrm{~g} / \mathrm{l})$. Results on oxygenation are presented as the $\mathrm{PaO}_{2} / \mathrm{FiO}_{2}$.

A left carotid arterial line was inserted, and a Swan-Ganz catheter was introduced into the right jugular vein. The bladder was catheterized (balloon catheter Ch 20; Rüsch AG, Kernen, Germany) and peritoneal fluid drained via a multihole catheter.

\section{Endotoxin infusion and nitric oxide challenges}

After a stabilization period of 1 hour and baseline measurements, lung injury was induced by an endotoxin infusion (30 $\mu \mathrm{g} / \mathrm{kg} / \mathrm{hour}$, Escherichia coli lipopolysaccharide 0111:B4; Sigma-Aldrich, Stockholm, Sweden) via a peripheral venous line over 2 hours. The animals were then given INO for a period of 10 minutes. A single exposure to INO was given to 20 animals at 4 hours and to another eight animals at 6 hours after onset of lung injury. Nine out of the 20 animals exposed to INO at 4 hours received a second INO challenge at 6 hours after the onset of lung injury, with the purpose of observing whether an animal changes its response to INO over time [10].

Nitric oxide (1,000 ppm; AGA Gas AB, Lidingö, Sweden) was delivered in an air/oxygen mixture from a low-flow air-oxygen blender (AGA AB, Sundbyberg, Sweden) into the low-pressure gas-flow inlet of the ventilator. The NO level was adjusted to an inspiratory concentration of $40 \mathrm{ppm}$, as measured by an NO chemiluminescence analyzer (9841 NOx; Lear Siegler Measurement Controls Corporation, Englewood, CO, USA). All measurements and blood gas sampling were collected after 10 minutes of $\mathrm{NO}$ inhalation. A positive response to INO was defined as a $20 \%$ increase in $\mathrm{PaO}_{2}$ compared with pretreatment levels [7].

At the end of the experiment the pigs were killed by an intravenous injection of potassium chloride $(40 \mathrm{mmol})$.

\section{Physiological parameters}

The systemic mean arterial pressure, the mean pulmonary arterial pressure (MPAP) and the central venous pressure were continuously displayed and recorded (series 7010 Tram; Marquette Electronics, Milwaukee, WI, USA). The pulmonary capillary wedge pressure was measured intermittently, and the systemic vascular resistance and the pulmonary vascular resistance calculated. Cardiac output was determined by thermodilution using an injection of $8 \mathrm{ml}$ cold $5 \%$ glucose solution. Arterial and mixed venous blood gases (oxygen partial pressure, carbon dioxide partial pressure, hemoglobin oxygen saturation), $\mathrm{pH}$, and hemoglobin were analyzed by spectrophotometry with the analyzer calibrated for porcine blood (ABL 300 and OSM 3; Radiometer, Copenhagen, Denmark).

\section{Blood sampling}

Arterial blood samples were taken at baseline (TO) and every hour thereafter until 4 hours (T1 to T4) or 6 hours (T1 to T6); the blood samples at 4 hours and 6 hours were drawn just before NO inhalation. The total leukocyte count with the respective percentages of neutrophils and macrophages were obtained as well as the percentages of proteins, endotoxin (for control of the efficacy of the endotoxin infusion and evolution over time), cytokines (TNF $\alpha, \mathrm{IL}-8$ ), prostanoids (thromboxane $\mathrm{B}_{2}\left(\mathrm{TXB}_{2}\right), 6$-keto-prostaglandin $\mathrm{F} 1$ alpha $\left(\mathrm{PGF}_{1 \alpha}\right)$ and prostaglandin $\mathrm{F} 2$ alpha $\left(\mathrm{PGF}_{2 \alpha}\right)$ ), leucotriene $\mathrm{B}_{4}\left(\mathrm{LTB}_{4}\right)$, endothelin-1 (ET-1) and nitrates. 


\section{Biochemical parameters measurements}

For endotoxin measurements, blood was drawn into pyrogenfree Chromogenix tubes and analyzed using a quantitative endpoint chromogenic method (Coatest; Chromogenix AB, Mölndal, Sweden). The E. coli 0111:B4 reference endotoxin was the standard curve performed in pig serum or in sterile pyrogen-free water. The endotoxin value was expressed in picograms per milliliter and the lowest limit of detection was 5 $\mathrm{pg} / \mathrm{ml}[11]$.

Cytokines (TNF $\alpha$, IL-8) were measured in duplicate using commercially available cytokine-specific ELISA kits (Quantikine $^{\circledR} ;$ R\&D Systems, Oxon, UK). The limits of sensitivity were $4.4 \mathrm{pg} / \mathrm{ml}$ for TNF $\alpha$ and $10 \mathrm{pg} / \mathrm{ml}$ for IL-8.

Prostanoids $\left(\mathrm{TXB}_{2}\right.$, 6-keto-PGF $\left.\mathrm{PG}_{1 \alpha}, \mathrm{PGF}_{2 \alpha}\right)$ and $\mathrm{LTB}_{4}$ were measured by competitive enzyme immunoassay using commercially available kits (Cayman, Ann Arbor, MI, USA), after extraction on a C-18 reverse phase cartridge (Sep-Pak-C18 cartridges; Pharmacia). The limits of sensitivity were $13 \mathrm{pg} / \mathrm{ml}$, $11 \mathrm{pg} / \mathrm{ml}, 8 \mathrm{pg} / \mathrm{ml}$ and $4 \mathrm{pg} / \mathrm{ml}$ for TXB $_{2}, 6$-keto-PGF ${ }_{1 \alpha}, \mathrm{PGF}_{2 \alpha}$ and $\mathrm{LTB}_{4}$, respectively.

ET-1 was measured by an immunometric assay using a commercially available kit (Cayman), after extraction on C-18 reverse phase cartridges. The limit of sensitivity was $1.5 \mathrm{pg} / \mathrm{ml}$.

The kits used for cytokines and ET-1 measurements were valid for humans and pigs. The kits used for prostanoids and $\mathrm{LTB}_{4}$ are not species specific. Nitrates were measured by the Griess reaction in the presence of nitrate reductase. Proteins were measured by the Folin-Ciocalteu technique.

\section{Statistical analysis}

Data are presented as the mean \pm standard deviation or as the median (25th percentile to 75th percentile) when not normally distributed. One-way analysis of variance with Bonferroni correction was used for multiple comparisons. For comparison of two groups of values between responders and nonresponders or between two sampling times, we used the Wilcoxon test or the $t$ test without correction for multiple comparisons. Comparisons between selected physiological and biochemical parameters not normally distributed were made by nonparametric correlation using the Spearman $\rho$ coefficient (SPSS 14.0 for Windows; SPSS Inc., Chicago, IL, USA). Statistical significance was considered $P<0.05$.

\section{Results Physiological events}

There were no differences in any hemodynamic or gas exchange variable between 4 hours and 6 hours after induction of lung damage. The data for the single exposure to INO at 4 hours and 6 hours were therefore pooled for analysis.

\section{Effect of endotoxin}

Endotoxin exposure caused an increase in the MPAP and the pulmonary vascular resistance, whereas the cardiac output remained unaltered. There was a mean decrease in the mean arterial pressure. The systemic vascular resistance fell as well, but the decrease was only significant in nonresponders. Arterial oxygenation $\left(\mathrm{PaO}_{2} / \mathrm{FiO}_{2}\right)$ was reduced and the $\mathrm{PaCO}_{2}$ increased with endotoxin infusion (Table 1).

\section{Effect of inhaled nitric oxide}

Inhalation of $\mathrm{NO}$ caused an increase in the $\mathrm{PaO}_{2} / \mathrm{FiO}_{2}$ of 50 $\mathrm{mmHg}\left(+22 \%\right.$ of pre-INO $\left.\mathrm{PaO}_{2} / \mathrm{FiO}_{2}\right)$ when all pigs were pooled $(n=28)$. A decrease in the MPAP was seen with a mean of $8 \mathrm{mmHg}(P<0.05)$. There were $60 \%$ responders when data from all pigs were pooled. When the pigs were divided into a responder $\left(20 \%\right.$ increase in the $\left.\mathrm{PaO}_{2} / \mathrm{FiO}_{2}\right)$ and a nonresponder group, $65 \%$ of animals at 4 hours and $32 \%$ of animals at 6 hours after onset of endotoxin exposure were assigned the responder group. The $\mathrm{PaO}_{2} / \mathrm{FiO}_{2}$ increased from $215 \mathrm{mmHg}$ to $316 \mathrm{mmHg}$ in the responder group $(P<0.05)$, and the MPAP decreased from $40 \mathrm{mmHg}$ to $30 \mathrm{mmHg}(P<$ 0.05) (Table 1). The MPAP was significantly higher in the future responders and the decrease in MPAP during INO was twice as marked compared with the nonresponder group (Table 1). The venous admixture was reduced in the responder group during INO whereas it tended to increase in the nonresponder group (Table 1).

Of those nine animals exposed to a second NO challenge, seven pigs were responders at 4 hours and only two pigs were considered responders at 6 hours. Five animals had therefore become nonresponders at 6 hours after being considered responders at 4 hours. These five pigs increased the $\mathrm{PaO}_{2} /$ $\mathrm{FiO}_{2}$ by $75 \%(P<0.05)$ at the first exposure to INO but had no change in the $\mathrm{PaO}_{2} / \mathrm{FiO}_{2}$ at the second exposure.

\section{Blood cells and protein}

Effect of endotoxin

The total leukocyte count decreased early, at T1 (1 hour after onset of endotoxin infusion) and on endotoxin exposure, and remained low until the end of the experiment (T4 to T6). Initially the neutrophils decreased as a fraction of the total leukocyte count, whereas macrophages increased. By the end of the experiment, the fraction of neutrophils had increased above baseline and macrophages were lowered. Platelets were decreased until T6. The blood protein concentration decreased until 3 hours after endotoxin administration and then remained low throughout the study period (Table 2).

\section{Response to inhaled nitric oxide}

In responders to INO the total leukocyte count and the fraction of neutrophils were higher compared with nonresponders $(P<$ 0.05 for both comparisons) (Table 3 ). Thrombocytes and proteins were not different in the two groups. 
Table 1

Hemodynamic parameters of responders and nonresponders

\begin{tabular}{|c|c|c|c|c|c|c|}
\hline \multirow[t]{2}{*}{ Parameter } & \multicolumn{3}{|c|}{ Responder $(n=15)$} & \multicolumn{3}{|c|}{ Nonresponder $(n=13)$} \\
\hline & Baseline TO & Endotoxin & Inhaled nitric oxide & Baseline T0 & Endotoxin & Inhaled nitric oxide \\
\hline $\mathrm{PaO}_{2} / \mathrm{FiO}_{2}(\mathrm{mmHg})$ & $502 \pm 42$ & $215 \pm 118^{*}$ & $316 \pm 141^{\dagger}$ & $462 \pm 62$ & $234 \pm 119^{*}$ & $225 \pm 126$ \\
\hline $\mathrm{PaCO}_{2}(\mathrm{mmHg})$ & $37 \pm 3.0$ & $50 \pm 11^{*}$ & $49 \pm 11$ & $39 \pm 4.8$ & $47 \pm 7.1^{*}$ & $51 \pm 9.2$ \\
\hline $\mathrm{pH}$ & $7.51 \pm 0.03$ & $7.29 \pm 0.10^{\star}$ & $7.22 \pm 0.29$ & $7.50 \pm 0.04$ & $7.34 \pm 0.08^{\star}$ & $7.30 \pm 0.08$ \\
\hline $\mathrm{CO}(\mathrm{I} / \mathrm{min})$ & $4.2 \pm 1.2$ & $4.4 \pm 0.9$ & $4.6 \pm 1.2$ & $4.1 \pm 0.9$ & $5.0 \pm 1.5$ & $5.4 \pm 1.7$ \\
\hline MPAP (mmHg) & $16 \pm 1.6$ & $40 \pm 7.7^{\star}$ & $30 \pm 7.5^{\dagger}$ & $15 \pm 2.3$ & $33 \pm 5.5^{\star} \neq$ & $28 \pm 5.0^{+}$ \\
\hline PVR (dyne/s/cm5) & $222 \pm 77$ & $617 \pm 231^{*}$ & $425 \pm 179^{\dagger}$ & $186 \pm 38$ & $407 \pm 172^{\star \neq}$ & $296 \pm 125$ \\
\hline CVP $(\mathrm{mmHg})$ & $4.0 \pm 1.6$ & $7.0 \pm 3.0^{*}$ & $7.6 \pm 3.9$ & $4.8 \pm 1.8$ & $8.4 \pm 3.2^{*}$ & $7.8 \pm 2.8$ \\
\hline $\mathrm{MAP}(\mathrm{mmHg})$ & $85 \pm 8.3$ & $80 \pm 17$ & $77 \pm 15$ & $81 \pm 9.8$ & $78 \pm 21$ & $75 \pm 22$ \\
\hline SVR (dyne/s/cm5) & $1,700 \pm 436$ & $1,380 \pm 288$ & $1,314 \pm 341$ & $1,541 \pm 339$ & $1,128 \pm 256^{\star} \neq$ & $1,032 \pm 292^{\ddagger}$ \\
\hline Qs/Qt (\%) & $9.4 \pm 2.8^{\ddagger}$ & $30 \pm 20^{*}$ & $23 \pm 17$ & $12 \pm 4.1^{\ddagger}$ & $24 \pm 9.0^{\star}$ & $29 \pm 12$ \\
\hline $\mathrm{Crs}\left(\mathrm{ml} / \mathrm{cmH}_{2} \mathrm{O}\right)$ & $27 \pm 3.8$ & $12 \pm 3.2^{*}$ & Not measured & $26 \pm 4.0$ & $13 \pm 3.2^{\star}$ & Not measured \\
\hline $\operatorname{Rrs}\left(\mathrm{cmH}_{2} \mathrm{O} \cdot \mathrm{s} / \mathrm{l}\right)$ & $15 \pm 4.0$ & $29 \pm 8.8^{*}$ & Not measured & $15 \pm 2.8$ & $29 \pm 8.6^{*}$ & Not measured \\
\hline
\end{tabular}

Parameters were recorded at baseline T0, 4 hours after the start of endotoxin infusion, and after 15 minutes of nitric oxide inhalation. Data represent the mean \pm standard deviation. CO, cardiac output; MPAP, mean pulmonary arterial pressure; PVR, pulmonary vascular resistance; CVP, central venous pressure; MAP, mean arterial pressure; SVR, systemic vascular resistance; Qs/Qt, intrapulmonary shunt; Crs, compliance of the respiratory system; Rrs, resistance of the respiratory system. ${ }^{\star} P<0.05$, endotoxin versus baseline; ${ }^{\dagger} P<0.05$, inhaled nitric oxide versus endotoxin; $\neq P<0.05$, responder versus nonresponder.

\section{Biochemical variables}

Effect of endotoxin

The endotoxin concentration in plasma increased after 1 hour of endotoxin infusion, slowly decreased after the cessation of the 2-hour infusion period and was no longer different from baseline at T6 (Table 2).

ET-1, $\mathrm{TXB}_{2}, \mathrm{PGF}_{2 \alpha}$, and TNF $\alpha$ all increased after 1 hour of endotoxin infusion and all remained elevated until the 6 hour measurement - except TNF $\alpha$, which was no longer different from baseline at T2. 6-Keto-PGF ${ }_{1 \alpha}$ and IL-8 differed from baseline after 2 hours of endotoxin infusion, and only 6-keto-PGF remained elevated at T4 and T6 (Table 2). The $\mathrm{LTB}_{4}$ levels did not differ from baseline.

The nitrate concentration in blood decreased initially but was not different from baseline in samples taken before the INO challenges at 4 hours and 6 hours (Table 2).

Positive correlation was seen between plasma concentrations of endotoxin and IL-8 $(\rho=0.62, P<0.01)$. Further positive correlations were seen between MPAP on one hand and IL-8 $(\rho=0.72, P<0.01)$ and ET-1 $(\rho=0.68, P<0.01)$, on the other. Protein in plasma showed negative correlation with all parameters except 6-keto-PGF ${ }_{1 \alpha}$ and TNF $\alpha$.
Response to inhaled nitric oxide

The five animals that switched from being responders at 4 hours to become nonresponders at 6 hours showed less endothelin (3.0 (2.5 to 7.5) pg/ml versus 0.1 (0.1 to 2.1$) \mathrm{pg} /$ $\mathrm{ml}, P<0.05)$ and less IL-8 (27 (16 to 28$) \mathrm{ng} / \mathrm{ml}$ versus $1.5(0$ to 3.25$) \mathrm{ng} / \mathrm{ml} ;, P<0.05)$ at the later occasion. The $\mathrm{PaO}_{2} /$ $\mathrm{FiO}_{2}$ increase or decrease is plotted against the concentration of ET-1 and IL-8 in Figure $1 \mathrm{a}, \mathrm{b}$.

Less ET-1 in blood was seen in nonresponders in the total material (28 pigs) (0.1 (0.1 to 8$) \mathrm{pg} / \mathrm{ml}$ versus 3.0 (1.8 to 8 ) $\mathrm{pg} / \mathrm{ml}$ in responders), but this difference did not reach significance.

Prostanoids $\left(\mathrm{PGF}_{2 \alpha}, \mathrm{TXB}_{2}\right.$, 6-keto-PGF ${ }_{1 \alpha}$ ) and $\mathrm{LTB}_{4}$ did not differ between responders and nonresponders, and neither did TNF $\alpha$ or nitrate concentrations (Table 3).

\section{Discussion}

Endotoxin has dramatic and complex effects on the structure and function of the lungs in intact animals and also on isolated lung cells [12]. The 2-hour endotoxin infusion in the present model resulted in a marked lung dysfunction with a $\mathrm{PaO}_{2} / \mathrm{FiO}_{2}$ around $200 \mathrm{mmHg}$ and pulmonary hypertension around 35 to $40 \mathrm{mmHg}$. Histological evidence of endotoxin-induced lung injury was previously performed and is described in a work by $\mathrm{Da}$ and colleagues [13]. The impairment remained stable over 
Table 2

\begin{tabular}{|c|c|c|c|c|c|c|c|}
\hline Parameter & TO $(n=28)$ & $\mathrm{T} 1(\mathrm{n}=18)$ & T2 $(n=18)$ & Т3 $(n=18)$ & $\mathrm{T} 4(\mathrm{n}=28)$ & T5 $(n=9)$ & T6 $(n=9)$ \\
\hline Leucocytes $\left(10^{6} / \mathrm{ml}\right)$ & $9.38 \pm 3.85$ & $2.02 \pm 0.5^{\star}$ & $1.44 \pm 0.89^{\star}$ & $0.97 \pm 0.19^{\star}$ & $1.13 \pm 0.49^{\star}$ & $1.25 \pm 0.41^{\star}$ & $1.86 \pm 0.79$ \\
\hline Neutrophils (\%) & $53 \pm 11$ & $27 \pm 10^{*}$ & $34 \pm 8.9^{*}$ & $43 \pm 15$ & $54 \pm 15$ & $73 \pm 16^{*}$ & $75 \pm 11^{*}$ \\
\hline Macrophage (\%) & $46 \pm 11$ & $71 \pm 11^{*}$ & $65 \pm 9.3^{*}$ & $55 \pm 15$ & $44 \pm 16$ & $27 \pm 17^{\star}$ & $23 \pm 11^{*}$ \\
\hline Thrombocytes $\left(10^{6} / \mathrm{ml}\right)$ & $384 \pm 73$ & $245 \pm 51^{*}$ & $208 \pm 48^{*}$ & $172 \pm 41^{*}$ & $177 \pm 55^{\star}$ & $178 \pm 65^{\star}$ & $191 \pm 52^{*}$ \\
\hline $\begin{array}{l}\text { Proteins } \\
(\mathrm{mg} / \mathrm{ml})\end{array}$ & 47 (42 to 52 ) & $\begin{array}{l}39 \\
(34 \text { to } 46)^{\star}\end{array}$ & $33(29 \text { to } 36)^{*}$ & $28(23 \text { to } 34)^{\star}$ & $35(26 \text { to } 38)^{*}$ & $27(22 \text { to } 31)^{*}$ & $34(29 \text { to } 35)^{\star}$ \\
\hline $\begin{array}{l}\text { Endotoxin } \\
(\mathrm{pg} / \mathrm{ml})\end{array}$ & $0(0$ to 0.04$)$ & $\begin{array}{l}758 \\
(542 \text { to } 1,008)^{\star}\end{array}$ & $\begin{array}{l}783 \\
(525 \text { to } 1,004)^{\star}\end{array}$ & $\begin{array}{l}200 \\
(125 \text { to } 755)^{\star}\end{array}$ & $85(27 \text { to } 413)^{*}$ & $12(5 \text { to } 73)^{\star}$ & 2.3 (0.3 to 11$)$ \\
\hline Endothelin-1 (pg/ml) & 0.1 & $5.0(4.0 \text { to } 6.0)^{*}$ & $\begin{array}{l}5.0 \\
(5.0 \text { to } 6.5)^{*}\end{array}$ & $\begin{array}{l}5.0 \\
(4.5 \text { to } 6.5)^{\star}\end{array}$ & $3.0(2.0 \text { to } 7.5)^{*}$ & $4.5(4 \text { to } 6.5)^{\star}$ & $0.6(0.1 \text { to } 8.8)^{\star}$ \\
\hline $\mathrm{PGF}_{2 \alpha}(\mathrm{pg} / \mathrm{ml})$ & $\begin{array}{l}225 \\
\text { (167 to } 344)\end{array}$ & $\begin{array}{l}1,011 \\
(859 \text { to } 1,216)^{*}\end{array}$ & $\begin{array}{l}1,301 \\
(766 \text { to } 1,690)^{*}\end{array}$ & $\begin{array}{l}1,439 \\
(971 \text { to } 1,708)^{\star}\end{array}$ & $\begin{array}{l}387 \\
(355 \text { to } 1513)^{\star}\end{array}$ & $\begin{array}{l}1,028 \\
(868 \text { to } 1,531)^{\star}\end{array}$ & $\begin{array}{l}1,224 \\
(333 \text { to } 1,562)^{*}\end{array}$ \\
\hline $\mathrm{TXB}_{2}(\mathrm{pg} / \mathrm{ml})$ & $\begin{array}{l}687 \\
\text { (581 to } 793\end{array}$ & $\begin{array}{l}3,110 \\
(2,617 \text { to } 3,546)^{*}\end{array}$ & $\begin{array}{l}2,824 \\
(2,120 \text { to } 3,287)^{*}\end{array}$ & $\begin{array}{l}2,409 \\
(2,129 \text { to } 3,110)^{*}\end{array}$ & $\begin{array}{l}4,103 \\
(1,521 \text { to } 4,986)^{*}\end{array}$ & $\begin{array}{l}2,107 \\
(1,648 \text { to } 2,430)^{*}\end{array}$ & $\begin{array}{l}3,150 \\
(891 \text { to } 4,002)^{*}\end{array}$ \\
\hline 6-keto-PGF $F_{1 \alpha}(\mathrm{pg} / \mathrm{ml})$ & $\begin{array}{l}294 \\
\text { (260 to } 518 \text { ) }\end{array}$ & $\begin{array}{l}749 \\
\text { (548 to } 1778)\end{array}$ & $\begin{array}{l}1,301 \\
(899 \text { to } 1,658)^{\star}\end{array}$ & $\begin{array}{l}732 \\
\text { (613 to } 1341)\end{array}$ & $\begin{array}{l}973 \\
(716 \text { to } 1,504)^{*}\end{array}$ & $\begin{array}{l}464 \\
\text { (332 to } 771)\end{array}$ & $\begin{array}{l}877 \\
\text { (534 to } 1,747)^{*}\end{array}$ \\
\hline $\operatorname{LTB}_{4}(\mathrm{pg} / \mathrm{ml})$ & $\begin{array}{l}36 \\
(23 \text { to } 46)\end{array}$ & 42 (22 to 210$)$ & 69 (24 to 225 ) & 48 (29 to 266 ) & 52 (42 to 423$)$ & 70 (43 to 187 ) & $\begin{array}{l}240 \\
\text { (42 to } 463)\end{array}$ \\
\hline $\mathrm{TNF} \alpha(\mathrm{pg} / \mathrm{ml})$ & 17 (11 to 22$)$ & $53(21 \text { to } 120)^{*}$ & 29 (5 to 52$)$ & 34 (14 to 69$)$ & 15 (10 to 38 ) & $26(0.5$ to 60$)$ & 3.5 (2.0 to 9.5$)$ \\
\hline IL-8 (ng/ml) & 0 & 2.0 (0 to 63$)$ & $117(108 \text { to } 127)^{*}$ & $116(104 \text { to } 126)^{*}$ & 31 (27 to 46 ) & 39 (19 to 52 ) & 6 (2 to 21 ) \\
\hline $\begin{array}{l}\text { Nitrates } \\
(\mathrm{nmol} / \mathrm{ml})\end{array}$ & $\begin{array}{l}211 \\
\text { (162 to } 309)\end{array}$ & $151(139 \text { to } 174)^{*}$ & $135(114 \text { to } 172)^{\star}$ & $133(119 \text { to } 149)^{\star}$ & $\begin{array}{l}189 \\
\text { (147 to } 237)\end{array}$ & $140(120 \text { to } 157)^{\star}$ & $\begin{array}{l}190 \\
(173 \text { to } 240)\end{array}$ \\
\hline
\end{tabular}

Data presented as the mean \pm standard deviation when normally distributed, or as the median (25th percentile to 75 th percentile). $P G F_{2 a}$ prostaglandin $\mathrm{F} 2$ alpha; $\mathrm{TXB}_{2}$, thromboxane $\mathrm{B}_{2} ; 6$-keto-PGF ${ }_{1 \alpha}, 6$-keto-prostaglandin $\mathrm{F} 1$ alpha; $\mathrm{LTB}_{4}$, leukotriene $\mathrm{B}_{4}$. ${ }^{*} P<0.05$ when different to baseline.

the 4-hour or 6-hour study period and 28 animals survived the whole experiment. Sixty percent of the animals were responders to a brief period of inhaled NO, similar to clinical observations in ARDS and sepsis [8].

The analysis of the animal group exposed twice to INO distinguished responders from nonresponders in terms of ET-1 and IL-8 levels. The responders had higher ET-1 and IL-8 levels.

\section{Inflammatory response to endotoxin}

There was no difference in the endotoxin concentration in plasma at 4 hours between responders and nonresponders, but the rapid decrease in endotoxin concentration in the nonresponder group during the last 2 -hour period suggests a faster metabolism of endotoxin in nonresponders. Endotoxin also binds to the endothelium, proteins and circulating cells, and this reduces the plasma concentration; however, whether this interacts with the vasodilating effect of inhaled NO is not clear.

The endotoxin infusion caused an early and severe leucopenia that may be explained by cell trapping and adhesion to the endothelium as well as dilution by edema formation. As shown earlier the fraction of neutrophils increased at the expense of the fraction of monocytes [10]. The higher neutrophil and macrophage count in responders than in nonresponders may illustrate a different inflammatory process due to the endotoxin infusion; however, this requires further study to be resolved. 
Table 3

Cells and inflammatory parameters at baseline and before inhaled nitric oxide (INO) for responders and nonresponders

\begin{tabular}{|c|c|c|c|c|c|c|}
\hline \multirow[t]{2}{*}{ Parameter } & \multicolumn{3}{|c|}{ Responders $(n=15)$} & \multicolumn{3}{|c|}{ Nonresponders $(n=13)$} \\
\hline & Baseline & Before INO & $P$ value & Baseline & Before INO & $P$ value \\
\hline Leucocytes $\left(10^{6} / \mathrm{ml}\right)$ & $10.4 \pm 4.4$ & $1.6 \pm 1.0^{+}$ & $\leq 0.01$ & $8.8 \pm 2.4$ & $0.9 \pm 0.3^{*}+$ & $\leq 0.01$ \\
\hline Neutrophils (\%) & $56 \pm 12$ & $65 \pm 14$ & 0.074 & $53 \pm 10$ & $48 \pm 17^{\star}$ & 0.45 \\
\hline Macrophage (\%) & $44 \pm 12$ & $34 \pm 15$ & 0.064 & $47 \pm 10$ & $51 \pm 17^{\star}$ & 0.45 \\
\hline Thrombocytes $\left(10^{6} / \mathrm{ml}\right)$ & $408 \pm 77$ & $185 \pm 54^{\dagger}$ & $\leq 0.01$ & $355 \pm 61$ & $175 \pm 68^{+}$ & $\leq 0.01$ \\
\hline Proteins (mg/ml) & $47 \pm 6.0$ & $33 \pm 5.4^{+}$ & $\leq 0.01$ & $46 \pm 6$ & $34 \pm 5^{+}$ & $\leq 0.01$ \\
\hline Endotoxin (pg/ml) & 0 & 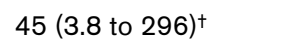 & $\leq 0.01$ & 0 (0 to 4.5$)$ & $32(0 \text { to } 392)^{+}$ & 0.011 \\
\hline Endothelin-1 (pg/ml) & 0 & $3.0(1.8 \text { to } 8)^{\dagger}$ & $\leq 0.01$ & 0 & 0.1 (0.1 to 8$)$ & 0.31 \\
\hline $\mathrm{PGF}_{2 \alpha}(\mathrm{pg} / \mathrm{ml})$ & 265 (236 to 327 ) & 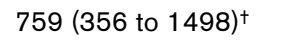 & $\leq 0.01$ & 218 (171 to 512$)$ & $380(342 \text { to } 1632)^{\dagger}$ & $\leq 0.01$ \\
\hline $\mathrm{TXB}_{2}(\mathrm{pg} / \mathrm{ml})$ & 692 (530 to 778 ) & $2881(860 \text { to } 4504)^{\dagger}$ & $\leq 0.01$ & $643(574$ to 821$)$ & $3883(2286 \text { to } 5051)^{\dagger}$ & $\leq 0.01$ \\
\hline 6-keto-PGF ${ }_{1 \alpha}(\mathrm{pg} / \mathrm{ml})$ & 291 (232 to 323 ) & $1023(810 \text { to } 1560)^{\dagger}$ & $\leq 0.01$ & 518 (274 to 899 ) & 603 (557 to 1099) & 0.33 \\
\hline $\mathrm{LTB}_{4}(\mathrm{pg} / \mathrm{ml})$ & 28 (16 to 41$)$ & $372(41 \text { to } 486)^{\dagger}$ & $\leq 0.01$ & 38 (9 to 48$)$ & $274(46 \text { to } 414)^{\dagger}$ & $\leq 0.01$ \\
\hline TNF $\alpha(p g / m l)$ & 15 (11 to 22$)$ & 18 (10 to 39$)$ & 0.083 & 12 (8 to 21 ) & 10 (5 to 27$)$ & 1.0 \\
\hline IL-8 (ng/ml) & 0 & $24(7.2 \text { to } 32)^{\dagger}$ & $\leq 0.01$ & 0 & $4(1.5 \text { to } 47)^{\dagger}$ & 0.03 \\
\hline Nitrates $(\mathrm{nmol} / \mathrm{ml})$ & 212 (173 to 352$)$ & $183(147 \text { to } 236)^{\dagger}$ & $\leq 0.01$ & 183 (133 to 255$)$ & $173(150$ to 212$)$ & 0.58 \\
\hline
\end{tabular}

Data present as the mean \pm standard deviation when normally distributed or as the median (25th percentile to 75 th percentile). PGF $2 \alpha$, prostaglandin $\mathrm{F} 2$ alpha; $\mathrm{TXB}_{2}$, thromboxane $\mathrm{B}_{2} ; 6$-keto- $\mathrm{PGF}_{10}$ 6-keto-prostaglandin $\mathrm{F} 1$ alpha; $\mathrm{LTB}_{4}$, leukotriene $\mathrm{B}_{4}$. ${ }^{*} P<0.05$ between responder and nonresponder, ${ }^{\dagger} P<0.05$ between baseline and before INO.

Endotoxin also caused a rapid release of inflammatory mediators and vasoactive substances. Prostanoids, $\mathrm{LTB}_{4}, \mathrm{ET}-1$, nitrates and cytokines increased in the blood. The vasoconstrictor $\mathrm{TXB}_{2}$ (a metabolite of thromboxane $\mathrm{A}_{2}$ ) also increased, and its concentration was always higher than that of the vasodilator 6-keto-PGF ${ }_{1 \alpha}$ (metabolite of prostacycline). The levels of the proinflammatory cytokine IL-8 followed the endotoxin evolution in blood.

\section{Endothelin-1 and inhaled nitric oxide}

The ET-1 in plasma rose rapidly and markedly already after 1 hour and paralleled the increase in blood endotoxin. There was a correlation between ET-1 levels and the pulmonary artery pressure. The higher MPAP in responders before INO challenge may therefore be explained by their higher ET-1 levels than in nonresponders. It may be argued that a general pulmonary vasoconstriction caused by an increased plasma concentration of ET-1 will facilitate or promote a positive response to INO and will improve oxygenation. This oxygenation improvement occurs because NO inhalation will cause vasodilation solely or preferentially in ventilated parenchyma, whereas the circulating ET-1 will promote vasoconstriction both in ventilated and nonventilated parenchyma. This mechanism may be comparable with the combination of almitrine with INO $[14,15]$. The stronger the pulmonary vasoconstriction, therefore, the more likely there will be a positive response to INO.
This conclusion is also supported by the findings in the limited number of pigs exposed to INO at 4 hours and at 6 hours that switched from response to nonresponse, with lower ET-1 concentrations when no longer responding to INO. A continuous endotoxin infusion may have led to further responders since endothelin correlates with endotoxin levels [16]. The high initial dose of endotoxin $(60 \mu \mathrm{g} / \mathrm{kg})$ produced severe physiologic dysfunction that did not allow a prolongation of the endotoxin infusion.

It is still a matter of debate whether INO increases ET-1, which would accentuate vasoconstriction in nonventilated parenchyma [17]. In contrast, there is evidence that INO decreases ET-1 secretion [18]. Rebound hypertension after withdrawal from INO is attributed to ET-1 in an endotoxin lung injury model [19]. The role of ET-1 during INO may be selective vasoconstriction in nonventilated parenchyma, whereas ET-1 induces vasoconstriction in the entire pulmonary vascular bed after withdrawal of INO.

In isolated-perfused lungs from endotoxin-challenged rats, when nitric oxide synthase 2 is inhibited, responsiveness to INO improved [20]. This could be explained by the predominant vasoconstrictive effects induced by the suppression of endogenous NO. We were not able, however, to separate 
Figure 1

(a)

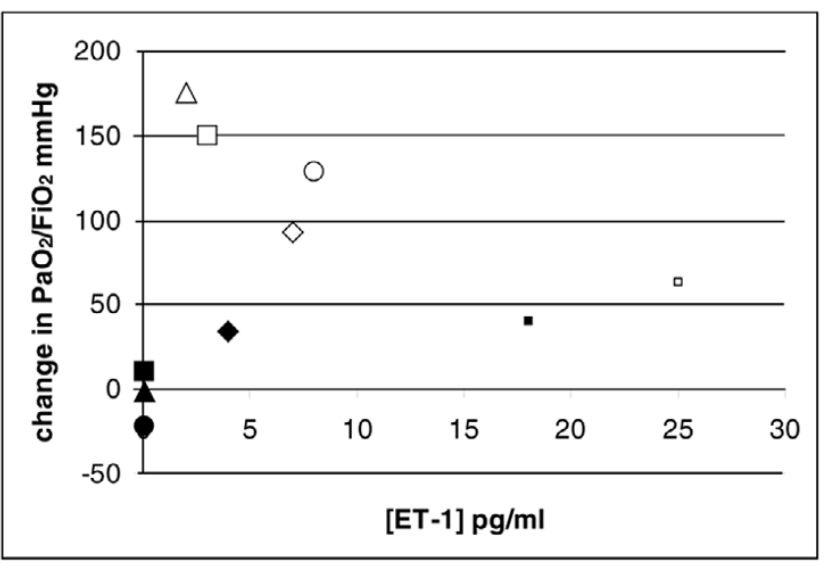

(b)

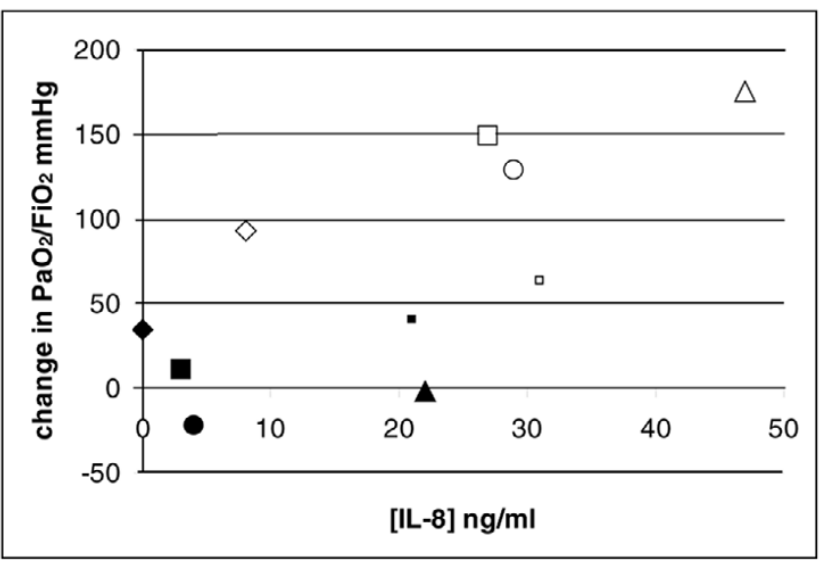

Levels of endothelin-1 and interleukin-8 compared with the increase or decrease of $\mathrm{PaO}_{2} / \mathrm{FiO}_{2}$. (a) Level of the endothelin-1 (ET-1) concentration $\left(\mathrm{pg} / \mathrm{ml}\right.$ ) compared with the increase or decrease of $\mathrm{PaO}_{2} / \mathrm{FiO}_{2}$ $(\mathrm{mmHg})$. All five animals exposed twice to inhaled nitric oxide decreased their ET-1 concentration level when changing from responder to nonresponder. (b) Level of IL-8 $(\mathrm{ng} / \mathrm{ml})$ compared with the increase or decrease of $\mathrm{PaO}_{2} / \mathrm{FiO}_{2}(\mathrm{mmHg})$. Levels of IL-8 decreased from response at the first exposure to nonresponse at the second exposure. Each symbol represents one animal; open symbol, first inhaled nitric oxide exposure; filled symbol, second exposure of the same animal with the same symbol.

responders from nonresponders by different nitrate levels in this in vivo model.

\section{Severity of pulmonary damage}

The severity of pulmonary dysfunction in terms of gas exchange and respiratory mechanics (compliance) did not differ between responders and nonresponders. The hemodynamics differed, however, with higher MPAP, pulmonary vascular resistance and systemic vascular resistance in the responders before INO challenge.
The degree of pulmonary damage separating responders from nonresponders may be an explanation for the varying responses to INO. Besides, a limitation may include the intravariability and intervariability of the animal lung injury model. On the contrary, most parameters of the inflammatory mediators measured here did not differ between responders and nonresponders - although IL-8 was, on an average, higher in the responder group [21]. This suggests that the severity of lung damage was much the same in the two groups. ET-1 and IL-8 were higher in responders, however, and ET-1 correlated to the MPAP. This observation may, as said above, explain higher values of the MPAP in responders. The separation between responders and nonresponders made on the basis of only two mediators (ET-1 and IL-8) may therefore support the hypothesis of a distinct mechanism, independent of the lung damage, responsible for the response to INO.

The results suggest that ET-1 may be a determining factor for a positive response to INO and for the decreased physiologic parameters. More severe pulmonary hypertension may be explained by higher levels of ET-1. INO, known for its antiinflammatory properties [22], could attenuate the effect of INO by decreasing ET-1 levels. This may explain the attenuation on oxygenation, when INO is administered for longer than 24 hours [4].

\section{Conclusion}

The presented endotoxin lung injury model demonstrates that responders to INO present more severe pulmonary dysfunction at a comparable inflammatory profile. This observation can be explained by elevated ET-1 levels correlated to the magnitude of pulmonary hypertension that may result in a positive response to INO. This additionally supports the hypothesis that INO acts by two distinct mechanisms; one is vasodilation in ventilated lung regions, and the other is vasoconstriction in poorly ventilated or nonventilated lung regions. Other inflammatory parameters did not vary between responders and nonresponders, and possibly document similar injuries to the lung and its vasculature in the present study.

\section{Key messages}

- Elevated concentration of endothelin-1 may mediate a positive response to inhaled nitric oxide.

- Responders to inhaled nitric oxide present more severe pulmonary dysfunction at a comparable inflammatory profile.

- Endothelin-1 levels correlate with the magnitude of pulmonary hypertension.

- Further support is added to the hypothesis that inhaled nitric oxide acts by two distinct mechanisms; one is vasodilation in ventilated lung regions, and the other is vasoconstriction in poorly ventilated or nonventilated lung regions. 


\section{Competing interests}

The authors declare that they have no competing interests.

\section{Authors' contributions}

ST performed the statistical analysis and interpretation of data, edited the manuscript and acquired funding. GD-D was involved with the biochemical analysis (immunoassays) and with editing the manuscript. EM performed the experiments and was involved in data acquisition. MN participated in the biochemical analysis. ML was involved in the study design and in revising the manuscript. GH has made a substantial contribution to the design and conception of the study, and to the interpretation of data.

\section{Acknowledgements}

The present study was supported by grants from the Swedish Medical Research Council (No 5315), the Swedish Heart and Lung Fund and the AGA Medical Fund and the Swiss National Science Foundation (PIOIB - 114967/1). The work is part of the project: Influence of endothelin activity on response to inhaled nitric oxide on ventilation perfusion distribution in acute lung injury, which was awarded The Alain Harf Award on Applied Respiratoy Physiology ESICM ECCRN Awards 2006. The assistance of Marie Ekberg-Richter, Lena Almgren, Annie Bjurebäck, Ann-Christine Linde, Hedy Magnusson and Agneta Pettersson, as well as Kere Frey, is highly appreciated. The work was performed at the Department of Medical Sciences, Clinical Physiology of the university hospital in Uppsala, Sweden.

\section{References}

1. Vincent JL, Sakr Y, Ranieri VM: Epidemiology and outcome of acute respiratory failure in intensive care unit patients. Crit Care Med 2003, 31:S296-S299.

2. Walmrath D, Schermuly R, Pilch J, Grimminger F, Seeger W: Effects of inhaled versus intravenous vasodilators in experimental pulmonary hypertension. Eur Respir J 1997, 10:1084-1092.

3. Rossaint R, Gerlach H, Schmidt-Ruhnke H, Pappert D, Lewandowski K, Steudel W, Falke K: Efficacy of inhaled nitric oxide in patients with severe ARDS. Chest 1995, 107:1107-1115.

4. Taylor RW, Zimmerman JL, Dellinger RP, Straube RC, Criner GJ, Davis K Jr, Kelly KM, Smith TC, Small RJ: Low-dose inhaled nitric oxide in patients with acute lung injury: a randomized controlled trial. JAMA 2004, 291:1603-1609.

5. Dellinger RP, Zimmerman JL, Taylor RW, Straube RC, Hauser DL, Criner GJ, Davis K Jr, Hyers TM, Papadakos P: Effects of inhaled nitric oxide in patients with acute respiratory distress syndrome: results of a randomized phase II trial. Inhaled Nitric Oxide in ARDS Study Group. Crit Care Med 1998, 26:15-23.

6. Lundin S, Mang H, Smithies M, Stenqvist O, Frostell C: Inhalation of nitric oxide in acute lung injury: results of a European multicentre study. The European Study Group of Inhaled Nitric Oxide. Intensive Care Med 1999, 25:911-919.

7. Krafft P, Fridrich P, Fitzgerald RD, Koc D, Steltzer H: Effectiveness of nitric oxide inhalation in septic ARDS. Chest 1996, 109:486-493.

8. Manktelow C, Bigatello LM, Hess D, Hurford WE: Physiologic determinants of the response to inhaled nitric oxide in patients with acute respiratory distress syndrome. Anesthesiology 1997, 87:297-307.

9. Hedenstierna $G$, Lattuada $M$ : Gas exchange in the ventilated patient. Curr Opin Crit Care 2002, 8:39-44.

10. Maurenbrecher H, Lamy M, Deby-Dupont G, Frascarolo P, Hedenstierna G: An animal model of response and nonresponse to inhaled nitric oxide in endotoxin-induced lung injury. Chest 2001, 120:573-581.

11. Nys M, Ledoux D, Canivet JL, De Mol P, Lamy M, Damas P: Correlation between endotoxin level and bacterial count in broncho- alveolar lavage fluid of ventilated patients. Crit Care Med 2000, 28:2825-2830.

12. Brigham KL, Meyrick $\mathrm{B}$ : Endotoxin and lung injury. $A m$ Rev Respir Dis 1986, 133:913-927.

13. Da J, Chen L, Hedenstierna G: Nitric oxide up-regulates the glucocorticoid receptor and blunts the inflammatory reaction in porcine endotoxin sepsis. Crit Care Med 2007, 35:26-32.

14. Gallart L, Lu Q, Puybasset L, Umamaheswara Rao GS, Coriat P, Rouby JJ: Intravenous almitrine combined with inhaled nitric oxide for acute respiratory distress syndrome. The NO Almitrine Study Group. Am J Respir Crit Care Med 1998, 158:1770-1777.

15. Papazian L, Roch A, Bregeon F, Thirion X, Gaillat F, Saux P, Fulachier V, Jammes Y, Auffray JP: Inhaled nitric oxide and vasoconstrictors in acute respiratory distress syndrome. Am J Respir Crit Care Med 1999, 160:473-479.

16. Snapper JR, Thabes JS, Lefferts PL, Lu W: Role of endothelin in endotoxin-induced sustained pulmonary hypertension in sheep. Am J Respir Crit Care Med 1998, 157:81-88.

17. Christou H, Adatia I, Van Marter LJ, Kane JW, Thompson JE, Stark AR, Wessel DL, Kourembanas S: Effect of inhaled nitric oxide on endothelin-1 and cyclic guanosine 5'-monophosphate plasma concentrations in newborn infants with persistent pulmonary hypertension. J Pediatr 1997, 130:603-611.

18. Kelly LK, Wedgwood S, Steinhorn RH, Black SM: Nitric oxide decreases endothelin-1 secretion through the activation of soluble guanylate cyclase. Am J Physiol Lung Cell Mol Physiol 2004, 286:L984-L991.

19. Chen L, He H, Fernandez Mondejar E, Freden F, Wiklund P, Alving $\mathrm{K}$, Hedenstierna G: Endothelin-1 and nitric oxide synthase in short rebound reaction to short exposure to inhaled nitric oxide. Am J Physiol Heart Circ Physiol 2001, 281:H124-H131.

20. Bopp C, Gust R, Taut F, Gries A, Martin E, Klein A: Responsiveness to inhaled NO in isolated-perfused lungs from endotoxinchallenged rats is dependent on endogenous nitrite/nitrate synthesis. Eur J Anaesthesiol 2007, 24:362-369.

21. Boutten A, Dehoux MS, Seta N, Ostinelli J, Venembre P, Crestani B, Dombret MC, Durand G, Aubier M: Compartmentalized IL-8 and elastase release within the human lung in unilateral pneumonia. Am J Respir Crit Care Med 1996, 153:336-342.

22. Busch T, Petersen B, Deja M, Donaubauer B, Laudi S, Jaumann S, Bercker S, Boemke W, Kaisers U: Endothelin-1 influences the efficacy of inhaled nitric oxide in experimental acute lung injury. Exp Biol Med (Maywood) 2006, 231:974-978. 